\title{
PELAKSANAAN PEMBERIAN BANTUAN HUKUM PADA TINGKAT PENYIDIKAN BERDASARKAN KITAB UNDANG-UNDANG HUKUM ACARA PIDANA (KUHAP) DI WILAYAH HUKUM POLRES BUKITTINGGI
}

\author{
ANNY YUSERLINA \\ Sekolah Tinggi Ilmu Hukum Putri Maharaja Payakumbuh \\ annyyuserlina87@gmail.com
}

\begin{abstract}
The provision of legal assistance at the level of investigation in the law of criminal justice in Indonesia is expected to provide maximum protection of the rights of life of suspects, especially those of weak and poor origin in the form of legal aid since the early stages of examination of suspects, Legal aid is not only interpreted as the right of the suspect since the investigation stage, but also as an obligation that must be fulfilled by every law enforcement apparat, especially investigators before starting an examination of suspects. Protection of the human rights of suspects since the stage of investigation is at least expected to be one of the factors that minimize the possibility of arbitrariness by law enforcement apparat and the possibility of irregularities in the application of criminal procedural legal procedures therefore examination at the level of investigation is important to get justice minimizing violations that can occur at any level that includes intimidation at the time of drafting News Of Inspection event so that apparat law enforcement stick to apparat law enforcement code of conduct and human rights values.
\end{abstract}

Keywords: Legal Aid, Investigation, Criminal Procedure Code, Bukittinggi Police.

\begin{abstract}
Abstrak: Pemberian bantuan hukum ditingkat penyidikan dalam hukum acara peradilan pidana di Indonesia diharapkan mampu memberikan perlindungan maksimal terhadap hak-hak hidup tersangka khususnya yang berasal golongan lemah dan miskin dalam bentuk bantuan hukum sejak tahap awal pemeriksaan terhadap tersangka,bantuan hukum tidakhanya dimaknai sebagai hak tersangka sejak tahap penyidikan, melainkan juga sebagai kewajiban yang harus dipenuhi oleh setiap apparat penegak hukum khususnya penyidik sebelum memulai pemeriksaan terhadap tersangka. Perlindungan hak asasi tersangka sejak tahap penyidikan setidaknya diharapkan menjadi salah satu faktor yang meminimalisasi kemungkinan terjadinya kesewenangan oleh apparat penegak hukum maupun kemungkinan terjadinya penyimpangan dalam penerapan prosedur hukum acara pidana oleh karena nya pemeriksaan pada tingkat penyidikan merupakan hal yang penting untuk mendapatkan keadilan meminimalisir pelanggaran yang dapat terjadi pada tiap tingkatan yang meliputi intimidasi pada saat penyusunan Berita Acara Pemeriksaan (BAP) sehingga apparat penegak hukum tetap berpegang pada pedoman perilaku apparat penegak hukum dan nilai Hak Asasi Manusia (HAM).
\end{abstract}

Kata Kunci: Bantuan Hukum, Penyidikan, KUHAP, Polres Bukittinggi.

\section{A. Pendahuluan}

Bantuan hukum merupakan pelayanan hukum (legal service) yang bertujuan untuk memberikan perlindungan hukum dan pembelaan terhadap hak-hak asasi tersangka atau terdakwa sejak ia ditahan sampai diperolehnya putusan pengadilan yang tetap. Yang dibela dan diberi perlindungan hukum bukan kesalahan tersangka atau terdakwa melainkan hak asasi tersangka atau terdakwa agar terhindar dari perlakuan 
dan tindakan tidak terpuji atau tindakan sewenang-wenang dari aparat penegak hukum. (H.M.A. Kuffal, 2004:158).

Bantuan hukum perwujudan Hak Asasi Manusia khususnya tersangka untuk tercapainya Due Proces Of Law (Proses hukum yang adil) dalam sistem Peradilan Pidana, dimana hak-hak tersangka harus dilindungi dan dijunjung tinggi, seperti: 1) Mendengar tersangka dalam memberikan keterangan tersangka harus dalam keadaan bebas, tidak mengalami tekanan fisik maupun phisikis; 2) Mendapat bantuan hukum dari Penasehat Hukum; 3) Bebas dalam melakukan pembelaan; 4) Menemui saksi; dan 5) Pembuktian kesalahannya melalui Pengadilan yang adil, tidak memihak.

Keberadaan advokat dalam semua tingkat pemeriksaan merupakan unsur utama dari Proces of law sebab kemungkinan unsur-unsur lainnya bisa berjalan dengan baik dengan kehadirannya dalam tingkat pemeriksaan penyidikan ini. Seperti halnya tersangka memberikan keterangannya secara bebas, yang sangat riskan diabaikan oleh oknum penyidik, karena tidak ada advokat yang mendampingi tersangka pada waktu pemeriksaan, yang pada akhirnya kelak tersangka akan mencabut keterangannya yang tertuang dalam Berita Acara Pemeriksaaan (BAP) dengan alasan pada waktu pemeriksaan di tingkat penyidikan ia mengalami berbagai tekanan dari penyidik, sehingga ia memberikan keterangan tersebut karena takut dan terpaksa.

Adanya ketidakmampuan masyarakat secara finansial untuk menuntut haknya sesuai dengan prosedur hukum, menuntut untuk diadakannya suatu kebijaksanaan sehingga dapat mengajukan suatu perkara dengan tidak terbentur oleh biaya, oleh karena itu diperlukan suatu prosedur untuk mengajukan perkara secara cuma-cuma atau tidak perlu membayar panjar perkara (prodeo). Sehingga bagi pihak yang kurang mampu, dapat mengajukan gugatan secara cuma-cuma yang disebut dengan berperkara secara prodeo (biaya). Hal tersebut sesuai dengan asas trilogi peradilan yaitu peradilan cepat, sederhana dan murah. (Sudikno Mertokusumo, 1998: 16).

Frans Hendra Winarta mengemukakan bahwa seringkali pihak yang miskin karena tidak tahu hak-haknya sebagai tersangka, diperlakukan tidak adil atau dihambat haknya untuk didampingi advokat. Hal ini tentu saja sangat merugikan pihak yang menuntut haknya dan yang nantinya di proses di pengadilan. Untuk menghalangi terjadinya hal tersebut, dibutuhkan suatu lembaga atau organisasi hukum yang memperjuangkan keadilan dan penegakan hukum seperti Lembaga Bantuan Hukum (LBH) yang mendampingi klien atau pihak yang dirugikan hak nya, dengan catatan klien atau pihak yang akan didampingi perkaranya lemah secara ekonomi atau financial. Hal ini diatur juga di dalam Pasal 1 ayat (1) dan (2) Undang-Undang Nomor 16 Tahun 2011 Tentang Bantuan Hukum yang menyatakan bahwa: "Bantuan Hukum adalah jasa hukum yang diberikan oleh Pemberi Bantuan Hukum secara cuma-cuma kepada Penerima Bantuan Hukum dan Penerima Bantuan Hukum tersebut adalah orang atau kelompok orang miskin". (Frans Hendra Winarta, 2000:96)

Pemberian bantuan hukum ditingkat penyidikan dalam hukum acara peradilan pidana di Indonesia diharapkan mampu memberikan perlindungan maksimal terhadap hak-hak hidup tersangka khususnya yang berasal golongan lemah dan miskin dalam bentuk bantuan hukum sejak tahap awal pemeriksaan terhadap tersangka,bantuan hukum tidakhanya dimaknai sebagai hak tersangka sejak tahap penyidikan, melainkan juga sebagai kewajiban yang harus dipenuhi oleh setiap apparat penegak hukum khususnya penyidik sebelum memulai pemeriksaan terhadap tersangka. Perlindungan hak asasi tersangka sejak tahap penyidikan setidaknya diharapkan menjadi salah satu 
faktor yang meminimalisasi kemungkinan terjadinya kesewenangan oleh apparat penegak hukum maupun kemungkinan terjadinya penyimpangan dalam penerapan prosedur hukum acara pidana oleh karena nya pemeriksaan pada tingkat penyidikan merupakan hal yang penting untuk mendapatkan keadilan meminimalisir pelanggaran yang dapat terjadi pada tiap tingkatan yang meliputi intimidasi pada saat penyusunan Berita Acara Pemeriksaan (BAP) sehingga apparat penegak hukum tetap berpegang pada pedoman perilaku apparat penegak hukum dan nilai Hak Asasi Manusia (HAM).

\section{B. Metodologi Penelitian}

Berkaitan dengan penulisan karya ilmiah ini, penulis menggunakan pendekatan penelitian yuridis empiris yaitu penelitian yang menguji efektifitas hukum dalam pelaksanaannya di lapangan. Penulisan ini menggunakan cara studi lapangan (Empiric Research). Studi lapangan yang dilakukan dalam rencana penelitian ini adalah upaya untuk mencari, menemukan dan mengumpulkan data-data yang bersifat primer. Dalam hal ini penulis akan melakukan usaha untuk memperoleh data-data yang dimaksud dengan cara menyelenggarakan tanya jawab (wawancara) bersama para narasumber diantaranya Kasat Reskrim, Kanit Reskrim dan Penyidik Pembantu di Polres Bukittinggi. Analisis data yang dipergunakan dalam penelitian ini adalah analisis kualitatif dan penarikan kesimpulan dilakukan dengan metode induktif, yaitu menguraikan hal-hal yang bersifat khusus lalu menarik kesimpulan yang bersifat umum sesuai dengan permasalahan yang dibahas dalam penelitian.

\section{Hasil dan Pembahasan}

\section{Pelaksanaan Pemberian Bantuan Hukum Bagi Tersangka di Tingkat Penyidikan Di Wilayah Hukum Polres Bukittinggi}

Pelaksanaan pemberian bantuan bagi tersangka di wilayah hukum Polres Bukittinggi telah dilaksanakan sesuai dengan aturan sebagaimana yang diatur dalam Pasal 54 KUHAP, namun dalam pelaksanaannya belum maksimal, hal ini terlihat dari jumlah kasus yang terjadi di Polres Bukittinggi masih terdapat beberapa orang tersangka yang tidak mendapatkan bantuan hukum di tingkat penyidikikan untuk kepentingan pembelaan, tersangka berhak mendapat bantuan hukum baik dari seorang atau lebih penasihat hukum selama dalam waktu dan pada setiap tingkat pemeriksaan, menurut tata cara yang di atur dalam Undang-undang ini. Adapun prosedur untuk pemberian bantuan hukum di tingkat penyidikan di wilayah hukum Polres Bukittinggi adalah sebagai berikut: 1) Mengajukan permohonan secara tertulis yang berisi paling sedikit identitas Pemohon Bantuan Hukum dan uraian singkat mengenai pokok persoalan yang dimohonkan Bantuan Hukum; 2) Menyerahkan dokumen yang berkenaan dengan Perkara; dan 3) Melampirkan surat keterangan miskin dari Lurah, Kepala Desa, atau pejabat yang setingkat di tempat tinggal Pemohon Bantuan Hukum.

Pemberian Bantuan Hukum dilaksanakan oleh Pemberi Bantuan Hukum, yang harus memenuhi syarat: 1) Berbadan Hukum; 2) Terakreditasi; 3) Memiliki Kantor atau Sekretariat yang Tetap; 4) Memiliki Pengurus; dan 5) Memiliki Program Bantuan Hukum. Jadi pelaksanaan proses pemberian bantuan hukum yang dilakukan oleh Penyidik Polres Bukittinggi yaitu akan diuraikan berikut ini: 1) Pemeriksaan Tersangka; 2) Penyediaan Bantuan Hukum; 3) Pemberi bantuan hukum melakukan komunikasi dengan tersangka; dan 4) Pendampingan hukum oleh pemberi bantuan hukum. Pelaksanaan pemberian bantuan hukum terhadap tersangka sudah dilaksanakan sesuai dengan aturan namun belum semua kasus tindak pidana umum yang mendapatkan bantuan hukum di Polres Bukittinggi ini. 
Pada dasarnya pelaksanaan bantuan hukum tidak secara jelas dicantumkan dalam Pasal 56 KUHAP. Undang-Undang ini hanya menjelaskan mengenai hak tersangka yang mendapat bantuan hukum secara cuma-cuma. Bantuan hukum merupakan bagian dari hak yang diterima tersangka untuk mencari keadilan. Hak tersebut diperoleh agar mereka yang terkena kasus tindak pidana mendapat pendampingan hukum sampai perkaranya diproses di pengadilan. Pelaksanaan pemberian bantuan hukum bagi tersangka di Polres Bukittinggi merupakan suatu proses pemberian hak untuk tersangka dari penyidik sesuai dengan Pasal 114 KUHAP yang berbunyi: "Dalam hal seorang disangka melakukan suatu tindak pidana sebelum dimulainya pemeriksaan oleh penyidik, penyidik wajib memberitahukan kepadanya tentang haknya untuk mendapatkan bantuan hukum atau bahwa ia dalam perkaranya itu wajib didampingi oleh penasihat hukum".

Menurut isi Pasal tersebut dinyatakan bahwa polisi penyidik wajib memberitahukan hak-haknya kepada tersangka khususnya mengenai bantuan hukum. Jika Penyidik tidak memberitahukan hak-hak kepada tersangka maka pelaksanaan bantuan hukum tidak akan terlaksana. Tidak terlaksananya bantuan hukum ini mengakibatkan tersangka tidak didampingi Bantuan Hukum. Untuk memperoleh gambaran jelas mengenai pelaksanaan pemberian bantuan hukum di Polres Bukittinggi adalah proses pemberian bantuan hukum dari penyidik menyediakan bantuan hukum sampai tersangka menerima bantuan hukum. Menurut wawancara penulis dengan Kasat Reskrim Polres Bukittinggi, pelaksanaan proses pemberian bantuan hukum yang dilakukan oleh Penyidik Polres Bukittinggi akan diuraikan sebagai berikut di bawah ini.

Pemeriksaan Tersangka. Pada tahap pemeriksaan, sebelum tersangka diperiksa Polisi Penyidik karena melakukan tindak pidana, Penyidik memiliki tugas untuk wajib memberitahukan kepada tersangka mengenai hak menerima bantuan hukum sesuai dengan Pasal 114 KUHAP. Dalam hal ini tersangka yang menerima bantuan hukum harus memiliki kartu miskin yang diperolehnya dari Kantor Kelurahan/ Kecamatan setempat. Sebelum mendapatkan bantuan hukum, tersangka yang ingin diberi bantuan hukum harus memiliki syarat-syarat yang harus dipenuhi. Syarat-syarat tersebut yaitu: a) Mengajukan permohonan secara tertulis yang berisi sekurang-kurangnya identitas pemohon dan uraian singkat mengenai pokok persoalan yang dimohonkan Bantuan Hukum; b) Menyerahkan dokumen yang berkenaan dengan perkara; dan melampirkan surat keterangan miskin dari lurah, kepala desa, atau pejabat yang setingkat di tempat tinggal pemohon Bantuan Hukum; dan c) Dalam hal pemohon Bantuan Hukum tidak mampu menyusun permohonan secara tertulis, permohonan dapat diajukan secara lisan.

Penyediaan Bantuan Hukum. Setelah pemohon Bantuan Hukum melengkapi syarat-syarat tersebut, dalam hal penyediaan bantuan hukum, Penyidik menyediakan pemberi bantuan hukum yang sebelumnya telah bekerjasama dengan Polisi penyidik tersebut. Pemberi Bantuan hukum yang disediakan berasal dari Organisasi Bantuan Hukum dan biasanya sudah memiliki hubungan baik dengan Penyidik. Setelah itu, Penyidik meyediakan pemberi bantuan hukum untuk ditunjuk sebagai penasehat hukum bagi tersangka. Beberapa calon pemberi bantuan hukum yang ditunjuk maksimal 3 (tiga) orang untuk kemudian dipilih sendiri oleh tersangka. 
Pemberi bantuan hukum melakukan komunikasi dengan tersangka. Masingmasing pemberi bantuan hukum melakukan pendekatan selama 3 (tiga) hari dengan tersangka untuk lebih mengenal tentang masalah hukum yang dialami tersangka.

Pendampingan hukum oleh pemberi bantuan hukum. Dalam waktu tiga hari tersebut tersangka diperbolehkan untuk memilih sendiri pemberi bantuan hukumnya. Pada prinsipnya seorang tersangka diberi kebebasan untuk memilih sendiri penasihat hukumnya atau diberi kebebasan apakah ia akan didampingi penasihat hukum atau tidak. Namun demikian ada tersangka yang oleh Undang-undang di wajibkan untuk didampingi oleh penasehat hukum. Ketentuan yang mengatur tersangka atau terdakwa yang wajib didampingi oleh penasihat hukum ini dapat dipahami dari ketentuan Pasal 56 ayat (1) KUHAP yang selengkapnya berbunyi: ayat (1) Dalam hal tersangka atau terdakwa disangka atau didakwa melakukan tindak pidana yang diancam dengan pidana mati atau ancaman pidana lima belas tahun atau lebih atau bagi mereka yang tidak mampu yang diancam dengan pidana lima tahun atau lebih yang tidak mempunyai penasehat hukum sendiri, pejabat yang bersangkutan pada semua tingkat pemeriksaan dalam proses peradilan wajib menunjuk penasehat hukum bagi mereka. Ayat (2) Setiap penasehat hukum yang ditunjuk untuk bertindak sebagaimana dimaksud dalam ayat (1), memberikan bantuannya dengan cuma-cuma.

Apabila ditarik kesimpulan dari ketentuan yang mengatur tersangka yang wajib didampingi penasihat hukum, maka dapat dimengerti bahwa, tersangka atau terdakwa yang wajib didampingi penasihat hukum adalah : (a) diancam dengan pidana mati; (b) diancam dengan pidana lima belas tahun atau lebih; (c) tidak mampu dan diancam dengan pidana lima tahun atau lebih. Pada kenyataannya, pelaksanaan pemberian bantuan hukum dalam pelaksanaannya masih kurang optimal. Hal ini dapat dilihat masih ada tersangka yang tidak terpenuhi haknya untuk didampingi bantuan hukum seperti keterlambatan pemberian bantuan hukum serta penyidik masih kurang memahami tentang pemberian bantuan hukum yang terdapat dalam Pasal 56 ayat (1) dan (2). Pasal tersebut menyatakan bahwa tersangka wajib didampingi penasihat hukum. Khusus untuk tersangka yang tidak mampu/ miskin dengan ancaman pidana lima tahun atau lebih, berhak mendapat bantuan hukum yang disediakan oleh penyidik. Dalam penerapannya di Polres Bukittinggi terkait dengan pelaksanaan Pasal 115 KUHAP sebenarnya sudah berjalan dengan baik.

Berdasarkan penelitian dilapangan, untuk tersangka yang didampingi bantuan hukum, pada saat melakukan pemeriksaan terhadap tersangka yang tidak mampu (miskin), penyidik sudah memberikan kesempatan kepada pemberi bantuan hukum untuk mengikuti proses pendampingan pada tahap pemeriksaan namun prakteknya belum maksimal. Dalam pelaksanaan Bantuan Hukum bagi tersangka, walaupun ada pembatasan pendampingan dalam Pasal 115 KUHAP namun kami beserta jajaran penyidik berusaha tidak menghalangi penasehat hukum dalam proses pemeriksaan penyidikan, hal ini untuk menjaga kepastian hukum bagi tersangka, namun dalam hal pertanyaan yang dilakukan oleh penyidik penasehat hukum tidak biasa mengintervensi pertanyaan yang diberikan. Penasehat hukum hanya dapat mendengar, melihat dan menyaksikan jalannya pemeriksaan. Fungsi penasehat hukum hanya bersifat kordinatif dalam pemeriksaan penyidik, artinya penasehat hukum diperkenankan untuk mejelaskan kepada tersangka hal-hal yang menurut pertanyaan penyidik kurang dimengerti.

Penerapan Pasal 115 yang mengatur kedudukan penasehat hukum pada proses pemeriksaan penyidikan sepenuhnya merupakan kewenangan penyidik, tetapi untuk menjaga kepastian hukum penyidik harus dapat mengimplementasikan maksud dari E-ISSN: 2657-0300 Lembaga Penelitian dan Penerbitan Hasil Penelitian Ensiklopedia $\quad 241$ 
Undang-undang agar besifat fleksibel sepanjang hak yang diberikan penasehat hukum tidak mengganggu jalanya pemeriksaan. Selain itu, agar pelaksanaan pemberian bantuan hukum di Polres Bukittinggi berjalan optimal diharapkan dalam proses pemeriksaan dan penyidikan, pemberi bantuan hukum selalu berusaha menjalin hubungan dengan tersangka. Pemberi bantuan hukum berhak mengubungi tersangka dalam semua tingkat pemeriksaan dan berhak melakukan hubungan pembicaraan pada setiap saat, asal demi untuk kepentingan pembelaannya.

Penyidik berkewajiban memberitahukan kepada tersangka akan haknya untuk didampingi oleh Penasehat Hukum sebelum pemeriksaan dimulai. Berdasarkan ketentuan Pasal 114 dan 56 KUHAP, penyidik wajib memberitahukan kepada tersangka akan haknya untuk mendapat bantuan hukum sebelum dilakukan pemeriksaan, bahkan ada kewajiban bagi penyidik untuk menyediakan bantuan hukum bagi tersangka dalam tindak pidana tertentu, ketentuan tersebuat telah kami lakukan sebagaimana mestinya, tapi kenyataannya ada beberapa tersangka yang tidak mau didampingi oleh penasehat hukum, karena berbagai alasan, misalnya tidak ada uang membayar pengacara, bahkan ada anggapan kehadiran pengacara akan mempersulit/memperlambat pemeriksaan. Untuk mengatasi masalah ini kami menyuruh si tersangka untuk membuat surat pernyataan, bahwa yang bersangkutan tidak mau didampingi oleh pengacara.

Setiap hubungan dan pembicaraan pemberi bantuan hukum dengan tersangka dilakukan secara bebas tanpa pengawasan dari pejabat penyidik. Hubungan ini dimaksudkan agar tersangka dapat berkonsultasi tentang perkara yang dihadapinya dan menemukan solusi yang tepat dalam penyelesaian kasus hukum tersebut. Hak dari tersangka untuk mendapatkan Bantuan Hukum sebagaimana yang diatur dalam Pasal 56 KUHP ada dua cara: yaitu penasehat hukum yang disediakan oleh dan atas biaya tersangka sendiri dan Penasehat Hukum yang ditunjuk oleh pejabat Penyidik atas dasar kewajiban dengan biaya negara. Keadaan ini membawa implikasi bahwa due preces of law masih berada pada suatu sisi gelap seperti benang kusut yang sulit diselesaikan, yang jelas KUHAP tidak mencantumkan sanksi yang tegas atas diabaikannya ketentuan Pasal 56 KUHAP dimaksud, sehingga sewaktu pemeriksaan cenderung dikejar pengakuan dari tersangka oleh karena posisinya sebagai objek pemeriksaan bukan sebagai subjek, yang nota bene sangat bertentangan dengan asas Praduga tidak bersalah yang dianut oleh KUHAP. Disisi lain keberadaan KUHAP yang dalam teorinya membawa angin segar atas pengakuan dan perlindungan Hak Asasi Manusia khususnya tersangka ternyata jika dihadapkan dengan prakteknya masih belum terlaksana seperti yang diharapkan pembentuk Undang-Undang dimaksud.

Berdasarkan hasil wawancara dengan beberapa orang tersangka menunjukkan bahwa mereka tidak mampu untuk membayar penasehat hukum sendiri, akan tetapi mereka sadar dan mengerti akan kehadiran seorang Penasehat hukum untuk mendampingi mereka dalam pemeriksaan dimaksud, di samping itu ada juga beranggapan bahwa kehadiran penasehat hukum tidak akam membantu dalam pemeriksaan dimaksud bahkan sebaliknya mempersulit (mempromosikan mereka sebagai objek pemeriksaan) dan juga tidak tahu sama sekali arti pentingnya kehadiran penasehat hukum dimaksud pada saat pemeriksaan. 


\section{Kendala Yang Ditemui Dalam Pemberian Bantuan Hukum Bagi Tersangka Di Tingkat Penyidikan Di Wilayah Polres Bukittinggi}

Polres Bukittinggi dalam pelaksanaan pemberian bantuan hukum bagi tersangka masih banyak kendala yang ditemui. Beberapa kendala tersebut yaitu: Pertama, Terbatasnya dana untuk pelaksanaan pemberian bantuan hukum di Polres Bukittinggi terkait dengan dana bantuan hukum di Polres Bukittinggi untuk mewujudkan pemberian bantuan hukum tersebut masih mengalami kendala. Menurut Pasal 19 Undang-Undang Nomor 16 Tahun 2011 yang berbunyi: (1) Daerah dapat mengalokasikan anggaran penyelenggaraan Bantuan Hukum dalam Anggaran Pendapatan dan Belanja Daerah. (2) Ketentuan lebih lanjut mengenai penyelenggaraan Bantuan Hukum sebagaimana dimaksud pada ayat (1) diatur dengan Peraturan Daerah. Berdasarkan uraian tersebut di atas dapat dikemukakan bahwa Pemerintah daerah tidak dibebani kewajiban menyediakan anggaran bantuan hukum. Pada akhirnya alokasi anggaran untuk bantuan hukum kurang tersedia. Dalam Peraturan Daerah Kota Bukittinggi juga belum memuat tentang alokasi dana Bantuan Hukum. Oleh karena itu, dana yang diperoleh adalah dana yang diberikan oleh Lembaga Bantuan Hukum untuk membiayai pemberi bantuan hukum dan untuk berperkara. Dana yang disediakan untuk pemberian bantuan hukum bagi tersangka yang miskin.

Kedua, Ketersediaan Pemberi Bantuan Hukum masih belum tercukupi Ketersediaan Pemberi Bantuan Hukum di Polres Bukittinggi masih belum tercukupi. Kenyataannya di Polres Bukittinggi penyidik yang sudah beberapa kali menangani kasus tindak pidana, kurang tersedianya pemberi bantuan hukum menjadi suatu kendala dalam pelaksanaan pemberian Bantuan Hukum bagi tersangka di Polres Bukittinggi. Maraknya tindak pidana yang dilakukan oleh tersangka yang tidak mampu (miskin) membuat Polres Bukittinggi membutuhkan delapan sampai sepuluh pemberi bantuan hukum. Namun, Pemberi Bantuan Hukum di Polres Bukittinggi hanya tersedia tiga Pemberi Bantuan Hukum. Dengan demikian Polres Bukittinggi masih membutuhkan lima sampai tujuh pemberi bantuan hukum untuk memenuhi ketersediaan pemberi bantuan hukum agar menjadi seimbang.

Sumber Daya Manusia, Sumber daya manusia yaitu, personil Penyidik di Polres Bukittinggi. penyidik masih mengalami kendala karena ada sebagian dari polisi penyidik yang kurang memahami tentang pemberian bantuan hukum bagi tersangka yang tidak mampu (miskin). Dalam hal ini, pelaksanaan pemberian bantuan hukum dilaksanakan sebelum pemeriksaan tersangka oleh penyidik. Saat inilah petugas menanyakan apakah tersangka ingin didampingi penasehat hukum atau tidak. Sesuai Pasal 114 KUHAP, Penyidik wajib memberitahukan hak-hak tersangka khususnya untuk menerima bantuan hukum. Jika penyidik tidak memberitahukan, maka pelaksanaan bantuan hukum tidak dapat dilaksanakan.

Dari data informasi Penyidik di Polres Bukittinggi masih ada sebagian petugas penyidik yang kurang paham tentang hak tersangka untuk mendapat bantuan hukum khususnya bantuan hukum secara cuma-cuma sesuai dengan Undang-Undang Nomor 16 Tahun 2011 Tentang Bantuan Hukum. Hal ini yang meyebabkan penyidik akhirnya tidak menyediakan penasehat hukum dan hanya menyediakan surat penolakan untuk didampingi bantuan hukum yang ditandatangani oleh tersangka. 


\section{Jalan Yang Ditempuh Dalam Menghadapi Kendala Pemberian Bantuan Hukum Bagi Tersangka Di Polres Bukittinggi}

Upaya penyidik di Polres Bukittinggi dalam mengatasi kendala pelaksanaan bantuan hukum bagi tersangka sebagai upaya untuk mengurangi kendala yang muncul ketika proses pelaksanaan bantuan hukum. Meskipun upaya tersebut sudah dilakukan tetapi belum sepenuhnya terlaksana, sehingga hambatannya masih ada. Upaya-upaya tersebut diuraikan sebagai berikut:

Pertama, Melaporkan kepada pemerintah untuk mengalokasikan dana dalam pelaksanaan pemberian bantuan hukum bagi tersangka di Polres Bukittinggi. Pemerintah Daerah perlu memberikan perhatian khusus untuk pelaksanaan bantuan hukum sesuai dengan Undang-Undang Nomor 16 Tahun 2011 Tentang Bantuan Hukum. Hal-hal yang dilakukan antara lain dengan mengajukan dana alokasi yang sesuai untuk membiayai bantuan hukum, agar pemberi bantuan hukum dapat mendampingi tersangka yang tidak mampu (miskin) secara gratis sesuai dengan Pasal 56 ayat (2) KUHAP. Pada kenyataannya sesuai dengan Pasal 19 Undang-Undang Nomor 16 Tahun 2011 dana untuk memberikan bantuan hukum tidak wajib diberikan ke setiap daerah, sehingga Pemerintah Daerah berhak memberikan dana Bantuan hukum atau tidak. Hal ini membuat daerah kurang memiliki komitmen untuk mengalokasikan dana bantuan hukum. Komitmen inilah yang seharusnya Pemerintah Daerah lakukan untuk mewajibkan anggaran dana Bantuan Hukum masuk ke dalam Anggaran Pendapatan dan Belanja Daerah (APBD). Dengan demikian alokasi dana bantuan hukum dapat terpenuhi untuk masyarakat yang tidak mampu yang mencari keadilan. Untuk mengatasi kendala ini, upaya yang dilakukan Polres Bukittinggi adalah melakukan koordinasi dengan Lembaga Bantuan Hukum dan Pemerintah Daerah terkait dana Bantuan Hukum sehingga Pemerintah daerah dapat mengalokasikan dananya dalam hal pengalokasian dana bantuan hukum tersebut.

Kedua, Meningkatkan ketersediaan Pemberi Bantuan Hukum bagi tersangka yang tidak mampu (miskin). Dalam rangka meningkatkan ketersediaan Pemberi Bantuan Hukum terhadap tersangka yang tidak mampu (miskin) yakni, meningkatkan koordinasi antara kepolisian dengan Lembaga Bantuan Hukum. Dengan melakukan kerjasama ini, maka kebutuhan pemberi bantuan hukum untuk mendampingi tersangka yang tidak mampu (miskin) terpenuhi dan menjadi seimbang. Meningkatkan koordinasi dengan Lembaga Bantuan Hukum juga telah dilakukan dengan cara melakukan komunikasi mengenai Bantuan Hukum gratis bagi masyarakat yang miskin. Salah satu caranya yaitu mensosialisasikan Undang-Undang Nomor 16 Tahun 2011 Tentang Bantuan Hukum kepada aparat penegak dan penasehat hukum lewat POLMAS (Polisi Masyarakat). Program tersebut diadakan oleh Polres Bukittinggi setiap setahun sekali di sepanjang Jalan Sudirman Bukittinggi dengan cara mendirikan posko-posko. Tujuan didirikannya posko-posko yakni menjalin kerja sama dengan pemberi bantuan hukum dan bagi masyarakat yang ingin berkonsultasi mengenai bantuan hukum dapat mengunjungi posko tersebut. Sosialisasi yang diberikan Polisi Masyarakat tersebut yakni tentang pentingnya pelaksanaan pemberian Bantuan Hukum bagi tersangka yang tidak mampu (miskin) dan menjelaskan bahwa masyarakat tidak mampu (miskin) yang tersandung tindak pidana mempunyai hak-hak untuk mendapatkan keadilan khususnya memperoleh bantuan hukum. Dengan adanya bantuan hukum, proses penyidikan perkara pidana dapat berlangsung seimbang dan 
tersangka tidak takut lagi ketika diberikan pertanyaan-pertanyaan pada saat melakukan pemeriksaan atau penyidikan.

Ketiga, Meningkatkan Sumber Daya Manusia. Dalam rangka untuk meningkatkan sumber daya manusia yaitu profesionalisme polisi penyidik untuk mengatasi kurangnya pemahaman penyidik terhadap hak tersangka untuk mendapatkan bantuan hukum, upaya yang dapat dilakukan yaitu mengikut sertakan 3 (tiga) orang penyidik dalam sosialisasi atau penyuluhan hukum tentang bantuan hukum yang diadakan di Polres Bukittinggi. Sosialisasi juga dilakukan dengan bekerjasama antara Penyidik Polres Bukittinggi dengan Lembaga Bantuan Hukum Bukittinggi. Sosialisasi ini bertujuan untuk menambah wawasan dan pengetahuan hukum bagi penyidik tentang hak-hak tersangka yang tidak mampu/ miskin untuk mendapat bantuan hukum sesuai dengan Pasal 56 KUHAP dan Pasal 114 KUHAP.

\section{Penutup}

Dari hasil penelitian di atas bisa diambil kesimpulan bahwa, Pelaksanaan pemberian bantuan hukum bagi tersangka di Wilayah Hukum Polres Bukittinggi pada dasarnya bila dilihat dari segi yuridis normatif, KUHAP secara jelas telah mengatur tentang jaminan perlindungan hak asasi manusia bagi tersangka yang terindikasi melakukan tindak pidana kejahatan, khususnya pada pelaksanaan pemberian bantuan hukum bagi tersangka di Polres Bukittinggi. Kewenangan pihak penyidik cukup besar dalam pemberian bantuan hukum bagi tersangka yang miskin dan diancam pidana 5 (lima) tahun atau lebih yaitu ketika penyidik memberitahukan hak-hak tersangka untuk mendapat bantuan hukum. Dan kendala-kendala yang ditemui Polres Bukittinggi dalam pelaksanaan pemberian bantuan hukum bagi tersangka di Polres Bukittinggi adalah terbatasnya dana untuk pelaksanaan pemberian bantuan hukum bagi tersangka yang tidak mampu/miskin di Polres Bukittinggi, ketersediaan Pemberi Bantuan Hukum masih belum tercukupi/memadai dan Sumber Daya Manusianya, dan juga Upaya yang dilakukan untuk mengatasi kendala dalam pelaksanaan pemberian bantuan hukum bagi tersangka di Polres Bukittinggi adalah mengalokasikan dana untuk pelaksanaan pemberian bantuan hukum bagi tersangka yang tidak mampu di Polres Bukittinggi, meningkatkan ketersediaan Pemberi Bantuan Hukum bagi tersangka yang tidak mampu (miskin) dan meningkatkan Sumber Daya Manusia di Polres Bukittinggi.

\section{Daftar Pustaka}

H.M.A. Kuffal, 2004, Penerapan KUHAP Dalam Praktek Hukum, UMM Press, Malang.

Sudikno Mertokusumo, 1998, Hukum Acara Perdata Edisi kelima, Liberty, Yogyakarta.

Frans Hendra Winarta, 2000, Bantuan Hukum Suatu Hak Asasi Manusia Bukan Belas Kasihan, Elex Media Komputindo, Jakarta.

Financial artinya pembiayaan dalam Kamus Lengkap Bahasa Inggris, Pustaka Ilmu, Jakarta

Ratna Nurul Afiah, 1986, Praperadilan dan Ruang Lingkupnya, CV.Akademika Prasindo, Jakarta.

Adami Chazawi, 2005, Hukum Pidana Materiil dan Formil Korupsi di Indonesia, Bayumedia Publishing, Malang.

P.A.F. Lamintang, 1996, Dasar-Dasar Hukum Pidana Indonesia, PT. Citra Adityta Bakti. Bandung.

Tri Andrisman, 2007, Hukum Pidana, Universitas Lampung, Bandar Lampung. 
Wirjono Prodjodikoro, 1985, Asas-asas Hukum Pidana di Indonesia, PT.Eresco, Bandung.

R.Soesilo, 1984, Pokok-Pokok Hukum Pidana Peraturan Umum dan Delik-delik Khusus, Politea, Bogor.

Moeljatno, 1993, Azas-Azas Hukum Pidana, Rineka Cipta, Jakarta.

Pipin Syarifin, 2002, Hukum Pidana di Indonesia, CV.Pustaka Setia, Bandung. 